\title{
Flag Leaf Tolerance Study in Moroccan Barley (Hordeum vulgare L.) Varieties Submitted to a Severe Salt Stress
}

\author{
Driss Khattabi 1,*(D), El Hassan Sakar 2,*iD, Said Louahlia 1 (D) \\ 1 Natural Resources and Environment Laboratory, Faculty Polydisciplinary of Taza, Sidi Mohamed Ben Abdallah \\ University, B.P 1223, Taza-Gare, Taza, Morocco; driss.khattabi@usmba.ac.ma (D.K); said.louahlia@usmba.ac.ma (S.L); \\ 2 Department of Biology, Faculty of Sciences of Tetuan, Abdelmalek Essaâdi University, B.P. 2121 Mhannech II. 93002, \\ Tetuan, Morocco; hassan.sce@gmail.com (E.H.S); \\ * Correspondence: driss.khattabi@usmba.ac.ma (D.K); hassan.sce@gmail.com (E.H.S);
}

Scopus Author ID 57194743663

Received: 22.04.2021; Revised: 28.05.2021; Accepted: 3.06.2021; Published: 8.08.2021

\begin{abstract}
Salt stress is the most significant abiotic stress that can severely limit crop growth and productivity. This problem gets worse in the context of climate change. The Knowledge of genetic pool behavior under such environmental constraints is imperative for growing and research. Here, we tested salt stress tolerance in six barley varieties ('Amira', 'Oussama', 'Tamellalet', 'Adrar', 'Taffa', and 'Laanaceur'). To this end, a set of biochemical parameters (chlorophylls, proline, sodium, potassium levels and $\mathrm{K}^{+} / \mathrm{Na}^{+}$ratio) were measured. Salt constraint significantly reduced chlorophyll content and $\mathrm{K}^{+} / \mathrm{Na}^{+}$but resulted in high records of proline and $\mathrm{Na}^{+}$. Our outcomes show that treatment was the main variability since it explained more than $75 \%$ in data variability followed by variety effect. Wide variabilities were found among varieties for the measured parameters. Higher proline levels and $\mathrm{K}^{+} / \mathrm{Na}^{+}$ were found in 'Adrar', 'Tamellalet' and 'Taffa'. These two later varieties also displayed a higher record of $\mathrm{K}^{+}$. Lower $\mathrm{Na}^{+}$values were recorded in 'Laanaceur', 'Taffa', and 'Tamellalet', indicating their relative resistance against salt stress. In contrast, 'Oussama' and 'Amira' were relatively salt-sensitive due to their higher $\mathrm{Na}^{+}$and lowered $\mathrm{K}^{+} / \mathrm{Na}^{+}$and proline content. Resistant varieties could represent a good background for breeding for barley salt tolerance.
\end{abstract}

Keywords: Barley; Hordeum vulgare; salt stress; biochemical parameters; salt tolerance.

(C) 2021 by the authors. This article is an open-access article distributed under the terms and conditions of the Creative Commons Attribution (CC BY) license (https://creativecommons.org/licenses/by/4.0/).

\section{Introduction}

As a staple food in diverse civilizations, barley (Hordeum vulgare L.) has been noted historically for health-promoting benefits [1]. This crop is among the most tolerant salt crops grown in very high salinity areas [2]. In Morocco, barley is the second important cereal after wheat in terms of production and consumption [3]. Unfortunately, according to these authors, the arable land is increasingly affected by salinity, and the saline area reached more than 500,000 ha with damaged soil. Indeed, one of the main factors of soil degradation is salinization; about $19.5 \%$ of irrigated land and $2.1 \%$ of the arid land are threatened by salinity [4]. In semi-arid and arid regions, salinity is a major adverse factor, severely reducing plant growth and crop productivity [1,5-9].

Salt stress affects metabolic activities and nutrient absorption in plants [10]. It has been shown that the salt response depends on the species, variety, salt concentration, growing conditions, and stage of development $[10,11]$. Salt stress is widely reported to cause a series of unfavorable biochemical, physiological, and morphological changes that damage 
photosynthesis and other biochemical processes combined with plant growth, development and productivity [12,13]. Indeed, salinity is likely to disrupt the mineral nutrition of plants in interfering with the removal of some essential elements like potassium and calcium. In addition, the increase in $\mathrm{NaCl}$ concentration in the surrounding root area has been shown to cut down the absorption of potassium and calcium, interferes with their physiological functions [14].

Under salt stress, plants have improved their mechanisms to cope with salt constraints and to adapt to osmotic and ionic stress caused by salinity $[5,8,15]$. In this context, there is an association between osmoregulation and some potent osmoprotectants such as proline, soluble sugars, and potassium [16]. The change of proline concentration is generally related to the adaptation or tolerance of salt stress $[17,18]$. The known role of proline is membrane stabilization and osmotic adjustment, and detoxification of harmful ions in plants grown in saline environments [16]. Chlorophyll content was reported to decrease drastically in saltsensitive plants compared to salinity-tolerant plants [1]. High salinity results in reduced growth, which may be due to reduced leaf area and hence a lower light interception [19], even with low salt concentrations, there was a decrease in chlorophyll [6,20,21].

A literature review shows that there is a scarcity of information on Moroccan barley varieties' behavior under salt stress conditions. Hence the originality of our work, which had as goals, (i) to screen some biochemical parameters in six Moroccan barley varieties submitted to severe salt stress and (ii) to compare these varieties in terms of different measured biochemical parameters in order to select the most resistant varieties.

\section{Materials and Methods}

\subsection{Plant material and culture conditions.}

This work was carried out in a pot experiment in the growth chamber at the experimental station of the Polydisciplinary Faculty of Taza. Six barley (Hordeum vulgare L.) varieties used in this experiment were selected from several cultivars tested for sensitivity to salt stress, widely grown in Morocco. Seeds were supplied by the National Institute for Agricultural Research (INRA) and included in the official catalog of varieties (Table 1). They were grouped into two periods, namely old (released between 1980 and 1990) and intermediate (released between 1990 and 2000). Seeds were first disinfected with $5 \%(\mathrm{v} / \mathrm{v})$ commercial bleach sodium hypochlorite solution $(\mathrm{NaOCl})$ for 5 min and rinsed 3 times with distilled water as described in Taibi et al. (2006) and Athar et al. (2015) [22,23]. Twenty seeds of each variety were sown in $10 \mathrm{~L}$ plastic pots containing a mixture of soil and peat $(1: 1)$ in a completely randomized block design with three replicates.

Table 1. Description of the six varieties barley used in this study.

\begin{tabular}{|c|c|c|}
\hline Varieties & Origin & Year of release \\
\hline Old & 'Tamellalet' INRA Morocco & 1984 \\
\hline \multirow[t]{5}{*}{ Intermediates } & 'Laanaceur' INRA Morocco & 1991 \\
\hline & 'Taffa' INRA Morocco & 1994 \\
\hline & 'Oussama' INRA Morocco & 1995 \\
\hline & INRA Morocco & 1996 \\
\hline & INRA Morocco & 1998 \\
\hline
\end{tabular}

After germination, density was adjusted to three plants per pot, and the water content was adjusted at $80 \%$ f field capacity. Saline treatment was applied at the third-leaf stage. Treated plants were irrigated using saline solutions (up to $300 \mathrm{mM} \mathrm{NaCl}$ ). Salinity was 
monitored during the experiment period so that saline treatment was increased gradually to get an electrical conductivity in pots of $8 \mathrm{mS} / \mathrm{cm}$. Control pots were irrigated using distilled water without salt. Plants were grown at $22{ }^{\circ} \mathrm{C}$ under artificial light with PAR of $300 \mu$ mol photons.m ${ }^{-}$ ${ }^{2} \cdot \mathrm{s}^{-1}$. Fresh leaf samples used for analysis were harvested 75 days after the beginning of salt treatment.

\subsection{Determination of biochemical parameters.}

Proline accumulation was assessed as described in Bates et al. (1973) [24]. Briefly, 0.5 $\mathrm{g}$ of fresh leaf tissues (flag-leaf) from each treatment were added and homogenized in $10 \mathrm{~mL}$ of sulphosalicylic acid $(3 \% \mathrm{w} / \mathrm{v})$. The resulting homogenate was then filtrated. The extract was then treated with $2.5 \%$ ninhydrin solution and glacial acetic acid. The reaction mixture was kept at $100{ }^{\circ} \mathrm{C}$ for $60 \mathrm{~min}$ in a water bath. Toluene was added to separate chromophores. Optical density was recorded at $520 \mathrm{~nm}$ using a UV-VIS spectrophotometer (Jenway Model 16100, Dunmow, Essex, UK). The proline concentration was determined from a standard curve that was previously prepared using L-proline and expressed as $\mathrm{mg}$ of proline per $\mathrm{g}$ of fresh leaf weight (FW).

The chlorophyll content in flag leaves was determined using the DMSO method as described by Burnison (1980) [25]. To this end, sliced $20 \mathrm{mg}$ of leaf tissue (flag leaf) was placed in a vial containing $7 \mathrm{~mL}$ DMSO. Mixtures were incubated in a glass tube at $65^{\circ} \mathrm{C}$ with regular shaking intervals for at least 60 minutes (tissues became colorless). Absorbance was read at two wavelengths 663 and $645 \mathrm{~nm}$, using a UV-VIS spectrophotometer (Jenway Model 6100, Dunmow, Essex, UK). The content of chlorophyll a (Chl a), chlorophyll b (Chl b), and total chlorophyll (Chl T) was calculated using the following equations [26]. The content of each phlorophyll fraction (Chl a, Chl b, and $\mathrm{Chl} \mathrm{T}$ ) was then expressed as mg per $\mathrm{g}$ of leaf fresh weight $(\mathrm{FW})$.

$$
\begin{aligned}
\text { Chl a }(\mathrm{mg} / \mathrm{L}) & =\left(0.0127 \times \mathrm{A}_{663}\right)-\left(0.00269 \times \mathrm{A}_{645}\right) \\
\mathrm{Chl} \mathrm{b}(\mathrm{mg} / \mathrm{L}) & =\left(0.0229 \times \mathrm{A}_{645}\right)-\left(0.00468 \times \mathrm{A}_{663}\right) \\
\mathrm{Chl} \mathrm{T}(\mathrm{mg} / \mathrm{L}) & =\left(0.0202 \times \mathrm{A}_{645}\right)+\left(0.00802 \times \mathrm{A}_{663}\right)
\end{aligned}
$$

Where,

A645: Absorbance at $\lambda=645$,

A663: Absorbance at $\lambda=663$.

$\mathrm{Na}^{+}$and $\mathrm{K}^{+}$contents were determined using the flame photometer method [27]. Dry samples of $50 \mathrm{mg}$ of plant material (sampled from flag leaf) were treated with a mixture of 10 $\mathrm{mL}$ acid nitric-perchloric $(4: 1)$ at $120^{\circ} \mathrm{C}$ for $120 \mathrm{~min}$. The homogenate was diluted in distilled water $10 \%(\mathrm{v} / \mathrm{v})$ and filtered through a Whatman filter paper. The extract was used to determine free inorganic ions $\mathrm{K}^{+}$and $\mathrm{Na}^{+}$contents by flame emission photometry (Jenway PFP7, Jenway, Australia) described by Miller (1998) and Turan et al. (2010) [28,29]. $\mathrm{Na}^{+}$and $\mathrm{K}^{+}$contents were expressed as mg per $\mathrm{g}$ of $\mathrm{DW}$. The $\mathrm{K}^{+} / \mathrm{Na}^{+}$ratio was computed as a good criterion to assess salt stress tolerance [30].

\subsection{Statistical analysis.}

All determinations and calculations were made, at least, in triplicates. Combined analyses of variance (ANOVA) were performed over varieties and salt treatment. The least 
significant difference's test (LSD) was used to compare means for varieties and treatments at $5 \%$ as a probability level [31]. Correlations matrix among studied parameters was established based on mean values. Principal component analyses (PCA) were carried out using mean values. The STATGRAPHICS package, version XVII (Stat point Technologies, Inc., Virginia, USA) was used for all statistical analyses.

\section{Results and Discussion}

\subsection{Results.}

\subsubsection{Analyses of variance (ANOVA).}

Table 2 shows mean squares of the combined analyses of variance for proline content, chlorophyll a, chlorophyll b, total chlorophyll, sodium $\left(\mathrm{Na}^{+}\right)$, potassium $\left(\mathrm{K}^{+}\right)$, and $\mathrm{K}^{+} / \mathrm{Na}^{+}$ratio in leaves of six barley varieties grown under salt stress conditions. This table shows that both factors (treatment and variety) and their interaction significantly impacted most of the studied biochemical parameters. However, the main variability source was the treatment effect since it explained more than $77 \%$ of the total variance for $\mathrm{K}^{+}$and about $93 \%$ of the total variability in the remaining parameters. The magnitude of genotypic effect (variety) was of a lesser extent and allowed explaining around $3 \%$ of the total variance for the investigated parameters except for $\mathrm{K}^{+}$for which genotypic effect was about $17 \%$. Treatment by variety interaction was lower since it explained around $2 \%$ of the total variance in almost studied parameters.

Table 2. Mean squares of the combined analyses of variance for proline content (Proc), chlorophyll a (Chl a), Chlorophyll b (Chl b), Total Chlorophyll (Chl T), Sodium $\left(\mathrm{Na}^{+}\right)$, Potassium $\left(\mathrm{K}^{+}\right)$, and ratio $\left(\mathrm{K}^{+} / \mathrm{Na}^{+}\right)$in leaves of six barley varieties grown under salt stress conditions during the 2017-2018 crop season. Df $=$ degree of freedom. *, **, and *** indicate significance at $0.05,0.01$, and 0.001 levels of probability, respectively.

\begin{tabular}{l|l|l|l|l|l|l|l|l} 
Source of variation & Df & ProC & Chl a & Chl b & $\mathbf{C h l ~ T}$ & $\mathbf{N a}^{+}$ & $\mathbf{K}^{+}$ & $\mathbf{K}^{+} / \mathbf{N a}^{+}$ \\
\hline Treatment (Trt) & 1 & $331.30^{* * *}$ & $1.985^{* * *}$ & $0.569^{* * *}$ & $4.738^{* * *}$ & $382.67^{* * *}$ & $3.15^{* * *}$ & $19.34^{* * *}$ \\
\hline Varieties (Var) & 5 & $7.26^{* * *}$ & $0.118^{* * *}$ & $0.049^{* *}$ & $0.213^{* *}$ & $8.56^{* * *}$ & $0.71^{* * *}$ & 0.33 \\
\hline Replicate (Trt) & 4 & 0.04 & 0.006 & 0.004 & 0.015 & 0.21 & 0.01 & 0.15 \\
\hline Trt $\times$ Var & 5 & $10.08^{* * *}$ & $0.056^{*}$ & 0.012 & 0.069 & $8.34 * * *$ & $0.15^{* *}$ & $0.45^{*}$ \\
\hline Residual & 20 & 0.31 & 0.015 & 0.008 & 0.035 & 0.06 & 0.037 & 0.15 \\
\hline Total (corrected) & 35 & & & & & & &
\end{tabular}

\subsubsection{Treatment effects.}

Mean values of both salt treatment and control are summarized in Table 3. As evidenced in this table, there were significant variations between the salt treatment and control. Salt treatment displayed the greatest values of proline content $(8.22 \mathrm{mg} / \mathrm{g} \mathrm{FW})$ and sodium ion content $(8.37 \mathrm{mg} / \mathrm{g} \mathrm{DW})$. However, the lowest values of was recorded in chlorophyll a (1.31 $\mathrm{mg} / \mathrm{g} \mathrm{FW})$, chlorophyll b $(0.89 \mathrm{mg} / \mathrm{g} \mathrm{FW})$, total chlorophyll $(2.30 \mathrm{mg} / \mathrm{g} \mathrm{FW})$, sodium ion content $(1.85 \mathrm{mg} / \mathrm{g} \mathrm{DW})$, and $\mathrm{K}^{+} / \mathrm{Na}^{+}$ratio.

Table 3. Mean values of varieties and treatments for proline content (Proc), Chlorophyll a (Chl a), Chlorophyll b (Chl b), Total Chlorophyll $\left(\mathrm{Chl} \mathrm{T)}\right.$, Sodium $\left(\mathrm{Na}^{+}\right)$, Potassium $\left(\mathrm{K}^{+}\right)$, and ratio $\left(\mathrm{K}^{+} / \mathrm{Na}^{+}\right)$in leaves of six barley varieties grown under salt stress conditions during the 2017-2018 crop season. In each column, values followed by the same letter are not significantly different at $5 \%$ as a probability level.

\begin{tabular}{l|c|l|l|l|l|l|l} 
& $\begin{array}{c}\text { ProC } \\
(\mathrm{mg} / \mathrm{gFW})\end{array}$ & $\begin{array}{c}\mathbf{C h l ~ a} \\
(\mathrm{mg} / \mathrm{gFW})\end{array}$ & $\begin{array}{c}\mathbf{C h l ~ b} \\
(\mathrm{mg} / \mathrm{gFW})\end{array}$ & $\begin{array}{c}\mathbf{C h l ~ T} \\
(\mathrm{mg} / \mathrm{gFW})\end{array}$ & $\begin{array}{c}\mathbf{N a}^{+} \\
(\mathrm{mg} / \mathrm{gDW})\end{array}$ & $\begin{array}{c}\mathbf{K}^{+} \\
(\mathrm{mg} / \mathrm{gDW})\end{array}$ & $\mathbf{K}^{+} / \mathbf{N a}^{+}$ \\
\hline Varieties & & & & & & & \\
\hline 'Amira' & $3.48 \mathrm{e}$ & $0.92 \mathrm{~cd}$ & $0.70 \mathrm{~cd}$ & $1.72 \mathrm{~b}$ & $5.19 \mathrm{~b}$ & $2.89 \mathrm{ab}$ & $0.94 \mathrm{ab}$ \\
\hline 'Laanaceur' & $4.64 \mathrm{~d}$ & $1.26 \mathrm{a}$ & $0.82 \mathrm{ab}$ & $2.18 \mathrm{a}$ & $3.60 \mathrm{~d}$ & $2.73 \mathrm{~b}$ & $1.23 \mathrm{a}$ \\
\hline 'Oussama' & $4.88 \mathrm{~cd}$ & $1.14 \mathrm{ab}$ & $0.64 \mathrm{~d}$ & $1.88 \mathrm{~b}$ & $6.50 \mathrm{a}$ & $2.75 \mathrm{~b}$ & $0.69 \mathrm{~b}$
\end{tabular}




\begin{tabular}{l|l|l|l|l|l|l|l} 
& $\begin{array}{c}\text { ProC } \\
(\mathrm{mg} / \mathrm{gFW})\end{array}$ & $\begin{array}{c}\mathbf{C h l ~ a} \\
(\mathrm{mg} / \mathrm{gFW})\end{array}$ & $\begin{array}{c}\mathbf{C h l ~ b} \\
(\mathrm{mg} / \mathrm{gFW})\end{array}$ & $\begin{array}{c}\mathbf{C h l ~ T} \\
(\mathrm{mg} / \mathrm{gFW})\end{array}$ & $\begin{array}{c}\mathbf{N a}^{+} \\
(\mathrm{mg} / \mathrm{gDW})\end{array}$ & $\begin{array}{c}\mathbf{K}^{+} \\
(\mathrm{mg} / \mathrm{gDW})\end{array}$ & $\mathbf{K}^{+} / \mathbf{N a}^{+}$ \\
\hline 'Adrar' & $5.53 \mathrm{bc}$ & $1.07 \mathrm{bc}$ & $0.74 \mathrm{bcd}$ & $1.90 \mathrm{~b}$ & $6.53 \mathrm{a}$ & $2.04 \mathrm{c}$ & $1.35 \mathrm{a}$ \\
\hline 'Taffa' & $6.09 \mathrm{ab}$ & $0.91 \mathrm{~d}$ & $0.78 \mathrm{abc}$ & $1.79 \mathrm{~b}$ & $4.47 \mathrm{c}$ & $3.04 \mathrm{a}$ & $0.95 \mathrm{ab}$ \\
\hline 'Tamellalet' & $6.53 \mathrm{a}$ & $1.18 \mathrm{ab}$ & $0.89 \mathrm{a}$ & $2.14 \mathrm{a}$ & $4.37 \mathrm{c}$ & $2.67 \mathrm{~b}$ & $1.12 \mathrm{ab}$ \\
\hline Treatment & & & & & & & \\
\hline Control & $2.16 \mathrm{~b}$ & $1.31 \mathrm{a}$ & $0.89 \mathrm{a}$ & $2.30 \mathrm{a}$ & $1.85 \mathrm{~b}$ & $2.98 \mathrm{a}$ & $1.78 \mathrm{a}$ \\
\hline $\mathrm{NaCl}$ & $8.22 \mathrm{a}$ & $0.84 \mathrm{~b}$ & $0.64 \mathrm{~b}$ & $1.57 \mathrm{~b}$ & $8.37 \mathrm{a}$ & $2.39 \mathrm{~b}$ & $0.31 \mathrm{~b}$
\end{tabular}

\subsubsection{Genotypic effects.}

Table 3 presents the mean values of varieties of the investigated biochemical parameters. From these outcomes, there were significant variations among most of the six studied barley varieties. 'Tamallelet' was found to have the highest scores of proline $(6.53$ $\mathrm{mg} / \mathrm{g} \mathrm{FW})$ and chlorophyll b (0.89 $\mathrm{mg} / \mathrm{g} \mathrm{FW})$ contents. 'Taffa' displayed the smallest chlorophyll content $(0.91 \mathrm{mg} / \mathrm{g} \mathrm{FW})$ but the greatest value of $\mathrm{K}^{+}(3.04 \mathrm{mg} / \mathrm{g} \mathrm{DW})$. 'Adrar' was found to have the greatest values of $\mathrm{Na}^{+}(6.53 \mathrm{mg} / \mathrm{g} \mathrm{DW}), \mathrm{K}^{+}(2.04 \mathrm{mg} / \mathrm{g} \mathrm{DW})$ and $\mathrm{K}^{+} / \mathrm{Na}^{+}$ratio (1.35). The lowest values of chlorophyll b $(0.64 \mathrm{mg} / \mathrm{g} \mathrm{DW})$, and $\mathrm{K}^{+} / \mathrm{Na}^{+}$ratio $(0.69 \mathrm{mg} / \mathrm{g} \mathrm{DW})$ contents were recorded in 'Oussama', while 'Amira' was characterized by the lowest level of proline content (3.48 mg/g FW) and total chlorophyll $(2.18 \mathrm{mg} / \mathrm{g} \mathrm{FW})$. 'Laanaceur' presented the greatest scores of chlorophyll a $(1.26 \mathrm{mg} / \mathrm{g} \mathrm{FW})$, total chlorophyll $(2.18 \mathrm{mg} / \mathrm{g} \mathrm{FW})$, this variety showed the lowest value of sodium ion content $(3.6 \mathrm{mg} / \mathrm{g} \mathrm{DW})$.

\subsubsection{Correlations among the studied parameters.}

The correlations matrix among the studied parameters are shown in Table 4. According to our results, important positive and negative correlations were highlighted among the investigated biochemical parameters. In this regard, proline content was positively linked to sodium ion content and negatively associated with chlorophyll a, chlorophyll $b$, and total chlorophyll, potassium ion content, and the $\mathrm{K}^{+} / \mathrm{Na}^{+}$ratio. Moreover, chlorophyll a, b, and total chlorophyll values were positively and significantly associated with each other and with potassium ion content, but they were negatively associated with sodium ion content (Table 4). Potassium ion content was negatively linked to sodium ion content and positively associated with the $\mathrm{K}^{+} / \mathrm{Na}^{+}$ratio.

Table 4. Correlation coefficients among the studied parameters. Matrix correlation was carried out on mean values for each parameter. $* * *$, and $* * *$ indicate significance at $0.05,0.01$, and 0.001 levels of probability, respectively.

\begin{tabular}{|c|c|c|c|c|c|c|c|}
\hline & ProC & Chl a & $\mathrm{Chl} \mathrm{b}$ & Chl T & $\mathrm{Na}^{+}$ & $\mathrm{K}^{+}$ & $\mathrm{K}^{+} / \mathrm{Na}^{+}$ \\
\hline ProC & & $-0.641 * * *$ & $-0.544 * *$ & $-0.6278 * *$ & $0.671 * * *$ & $-0.800 * * *$ & $-0.684 * * *$ \\
\hline Chl a & & & $0.762 * * *$ & $0.941 * * *$ & $-0.734 * * *$ & $0.479 * *$ & $0.730 * * *$ \\
\hline Chl b & & & & $0.911 * * *$ & $-0.832 * * *$ & $0.569 * *$ & $0.826 * * *$ \\
\hline Chl T & & & & & $-0.812 * * *$ & $0.518^{*}$ & $0.797 * * *$ \\
\hline $\mathrm{Na}^{+}$ & & & & & & $-0.618^{* *}$ & $-0.986 * * *$ \\
\hline $\mathrm{K}^{+}$ & & & & & & & $0.689 * * *$ \\
\hline $\mathrm{K}^{+} / \mathrm{Na}^{+}$ & & & & & & & \\
\hline
\end{tabular}

\subsubsection{Principal Component Analysis.}

PCA was used as a multivariate statistical approach to discriminate between treatments and varieties. The two first PCs were retained since they allowed explaining over $89 \%$ of the total variability in our results. PC1 and PC2 accounted for $79 \%$ and $10 \%$, respectively. Points plotted on the surface delimited by axis 1 and 2 (Figure 1) are related to treatments, which seem to be distributed along PC1. Towards the positive direction of this component, $\mathrm{NaCl}$ treatment 
interacted with higher values of proline and sodium ion contents. Control interacted, on the positive side of PC1, with higher scores of chlorophyll a, b, and total chlorophyll, potassium ion content, and the $\mathrm{K}^{+} / \mathrm{Na}^{+}$ratio.

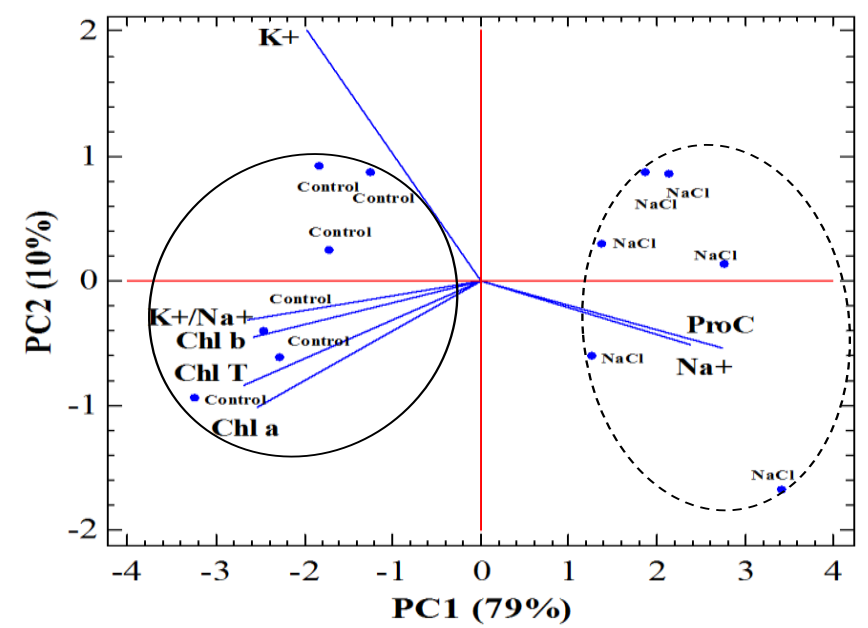

Figure 1. Principal component analysis (PCA) projections on PC1 and PC2. The eigenvalues are symbolized as blue segments representing traits that most affect each principal component. The 12 points are the treatment mean values of each studied parameter of six barley varieties grown under $\mathrm{NaCl}$ treatment during the 2017-2018 crop season. Proc: proline content, Chl a: Chlorophyll a, Chl b: Chlorophyll b, Chl T: Total Chlorophyll, $\mathrm{Na}^{+}$: Sodium, $\mathrm{K}^{+}$: Potassium, and $\mathrm{K}^{+} / \mathrm{Na}^{+}$: ratio of $\mathrm{K}^{+}$out of $\mathrm{Na}^{+}$.

Similar to Figure 1, points plotted on the surface delimited by axis 1 and 2 (Figure 2) are related to varieties. PC2 appears to discriminate between both 'Tamellalet' and 'Adrar' towards the negative side of PC2 with higher proline content, sodium ion, chlorophyll $\mathrm{a}, \mathrm{b}$, and total chlorophyll contents, and $\mathrm{K}^{+} / \mathrm{Na}^{+}$ratio. However, varieties 'Taffa', 'Amira', and 'Oussama' were distributed on the positive side of PC2 with higher scores of potassium ion content. Points related to 'Oussama' were close to 0 with lower scores of most studied parameters. PCA outcomes confirmed the results obtained in mean comparisons highlighted in Table 3.

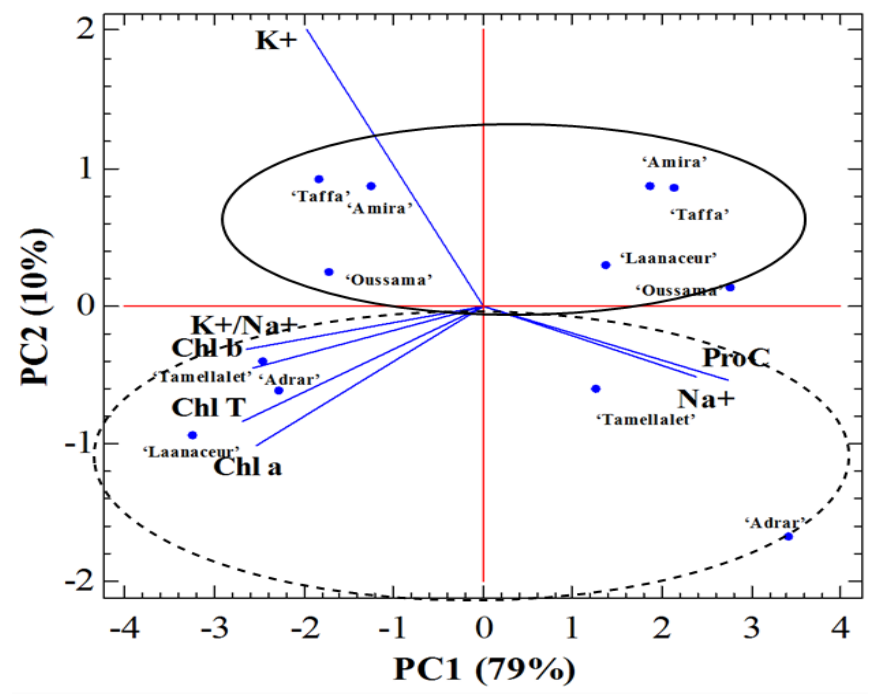

Figure 2. Principal component analysis (PCA) projections on PC1 and PC2. The eigenvalues are symbolized as blue segments representing traits that most affect each principal component. The 12 points are the mean accession values of each studied parameter of six barley varieties grown under $\mathrm{NaCl}$ treatment during the $2017-$ 2018 crop season. Proc: proline content, Chl a: Chlorophyll a, Chl b: Chlorophyll b, Chl T: Total Chlorophyll, $\mathrm{Na}^{+}$: Sodium, $\mathrm{K}^{+}$: Potassium, and $\mathrm{K}^{+} / \mathrm{Na}^{+}$: ratio of $\mathrm{K}^{+}$out of $\mathrm{Na}^{+}$. 


\subsection{Discussion.}

It is well known that salinity is a major abiotic stress that can severely reduce plant growth and crop productivity [32]. In this context, a pressing need is faced with overcoming such environmental constraints through technological means. Improving salinity tolerance requires a good knowledge of the physiological mechanisms linked to plant response to salt stress. In this work, we reported some biochemical responses of six Moroccan barley varieties under salt stress conditions. As highlighted in the results section, different biochemical parameters were mainly under treatment effects, while genotypic effects were lesser. Such results were in agreement with other previously reported works in barley and other crops $[1,10,12,33]$. It has been demonstrated that salt stress tolerance is highly inherited in barley [34-38]. It is controlled by the action of several genes that are highly influenced by the environment and genotype-by-environment interaction. Under salt constraint, [36] found higher values of heritability of leaf chlorophyll content $(0.86)$ and $\mathrm{Na}^{+}$and $\mathrm{K}^{+}$contents $(0.80)$.

Mean comparison between treatments (salt treatment and control) showed that applying salt stress reduced chlorophyll contents ( $\mathrm{a}, \mathrm{b}$, and the total), potassium ion content $\left(\mathrm{K}^{+}\right)$, and $\mathrm{K}^{+} / \mathrm{Na}^{+}$ratio on the one hand and increased the proline and sodium ion contents on the other hand. Our findings were in line with previously published works [1,10,12,39-41]. Under salt treatment, our varieties experienced a reduction exceeding $66 \%$ in the case of chlorophyll a and the $\mathrm{K}^{+} / \mathrm{Na}^{+}$ratio, about $30 \%$ in total chlorophyll, and less than $20 \%$ in chlorophyll $\mathrm{b}$ and potassium ion content compared to their respective controls. A differential reduction in different chlorophyll fractions has been reported by Athar et al. (2015) [23]. This chlorophyll content decline could be attributed to the chlorophyll synthesis inhibition, along with the activation of its enzymatic degradation via the chlorophyllase enzyme [21,42].

With regard to ions leakage, under salt stress, there was a significant increase in $\mathrm{Na}^{+}$, while $\mathrm{K}^{+}$and $\mathrm{K}^{+} / \mathrm{Na}^{+}$increased. These results were in agreement with published literature $[1,38,43,44]$. Under salt stress conditions, ions content and transport are altered as reviewed by Arzani and Ashraf (2006) [34]. Different strategies are used by plants to cope with the toxicity caused by $\mathrm{Na}^{+}$. In this context, some plants transport $\mathrm{Na}^{+}$to leaves and accumulate it in vacuoles, while others accumulate this ion at the roots level [45]. Increasing $\mathrm{K}^{+}$uptake is also a known strategy to counteract the entry of $\mathrm{Na}^{+}$[46]. Such decline in $\mathrm{K}^{+}$content at higher salinity levels could be ascribed to decreased competitive absorption with $\mathrm{Na}^{+}$[46]. This suggests that a strong ability of $\mathrm{K}^{+}$retention is thought to be one of the mechanisms behind their higher salt tolerance, as explained by Sun et al. (2015) [48]. Along with ionic leakage, the synthesis and accumulation of compatible solutes (like proline) are required to balance the osmotic potential of the vacuolar $\mathrm{Na}^{+}$[43]. Our results found a strong increase in proline levels under salt treatment compared to the control. This confirmed previously published works $[12,23,40,43]$. Proline synthesis, under salt conditions, is deemed to be one of the osmolytes widely reported to accumulate in plants under salt stress conditions. In fact, proline protects plants against salinity stress mostly via maintaining osmotic adjustment, ROS scavenging, and regulating antioxidant metabolites, but also modulating major enzymatic components involved in antioxidant defense system as reviewed in [49].

Vast differences were highlighted between all varieties studied here in terms of different biochemical parameters. These outcomes were in accordance with several studies that examined barley's biochemical and physiological behavior under salt stress conditions $[1,12,23,38,43]$. As outlined by other authors, such genotypic variations were assigned to a 
differentiated expression of genes that encode for these traits [12,48,51]. Moreover, several authors reported a positive correlation between free proline content, $\mathrm{K}^{+}$content, the $\mathrm{K}^{+} / \mathrm{Na}^{+}$ ratio on the one hand, and salt tolerance, on the other hand, suggesting the use of these parameters as indices to screen salt tolerance potentials among genotypes [1,43,52-54]. In our results, 'Tamellalet' and 'Taffa' were characterized by relatively higher proline, $\mathrm{K}^{+}$, and ratio $\mathrm{K}^{+} / \mathrm{Na}^{+}$but lower values of $\mathrm{Na}^{+}$. This suggests their salt stress resistance as compared to the remaining varieties. In contrast, 'Oussama' and 'Amira' were relatively salt-sensitive because of lower levels of proline, $\mathrm{Na}^{+}$, and $\mathrm{K}^{+} / \mathrm{Na}^{+}$ratio but a higher $\mathrm{Na}^{+}$content. Suppose we consider the $\mathrm{K}^{+} / \mathrm{Na}^{+}$ratio as a criterion to assess salt stress tolerance, as suggested by Widodo et al . (2009), Somasundaram et al. (2019), and Vasilakoglou et al.(2021) [38,43,55]. Both 'Laanacer' and 'Adrar' could be considered the most resistant varieties because of their relatively higher recorded values in the $\mathrm{K}^{+} / \mathrm{Na}^{+}$ratio. Correlations among different ions $\left(\mathrm{Na}^{+}\right.$, $\mathrm{K}^{+}$, and $\mathrm{K}^{+} / \mathrm{Na}^{+}$ratio) and among these ions and other induced salt stress metabolites like amino acids (including proline) were investigated previously. Such associations could be ascribed to genes linkage or pleiotropic effects between genes that encode these traits [36,50,56-58].

PCA was proved to be an efficient discriminative tool [59-65]. It was used as a multivariate statistical approach to discriminate among treatments and varieties. Several authors have used this tool for the same purpose in barley and other crops [11,38,42,66-81]. Our data variability was explained mainly by the two first components, as we indicated in the results' section. The first component was environmental, allowing a better separation of treatments (salt stress and control). In contrast, the second component is separated among varieties (genotypic component).

\section{Conclusions}

We evaluated biochemical responses of six Moroccan barley varieties grown under salt stress conditions. Data variability was mainly associated with the treatment effects, while genotypic effects were significant for different measured biochemical parameters. Salt treatment-induced proline accumulation and significant $\mathrm{Na}^{+}$content increase, while there were significant declines in terms of different chlorophyll fractions, $\mathrm{K}^{+}$, and $\mathrm{K}^{+} / \mathrm{Na}^{+}$ratio. Wide genotypic variations were revealed among all studied varieties. From these results, 'Tamellalet' and 'Taffa' had relatively higher proline, $\mathrm{K}^{+}$contents, and higher $\mathrm{K}^{+} / \mathrm{Na}^{+}$ratio, but these varieties showed lower $\mathrm{Na}^{+}$values, which could be linked to their salt stress resistance. In contrast, 'Oussama' and 'Amira' were relatively salt-sensitive because of lower proline levels, $\mathrm{Na}^{+}$contents, and $\mathrm{K}^{+} / \mathrm{Na}^{+}$ratio, coupled with higher $\mathrm{Na}^{+}$content. Considering the $\mathrm{K}^{+} / \mathrm{Na}^{+}$ratio as a criterion to assess salt stress tolerance, both 'Laanaceur' and 'Adrar' could be considered the most resistant varieties because of their relatively higher $\mathrm{K}^{+} / \mathrm{Na}^{+}$. Further investigations are needed to investigate the effects of salt constraint on phenology, yield, and grain quality in these varieties.

\section{Funding}

This research was funded by ARIMNet2 -Coordination of Agricultural Research in the Mediterranean, FP7-ERANET-2013 RTD -KBBE.2013.1.4-0.3, grant number 618127.

\section{Acknowledgments}

This research has no acknowledgment. 


\section{Conflicts of Interest}

The authors declare no conflict of interest.

\section{References}

1. Allel, D.; Ben-Amar, A.; Abdelly, C. Leaf photosynthesis, chlorophyll fluorescence and ion content of barley (Hordeum vulgare) in response to salinity. J Plant Nutr 2018, 41, 497-508, https://doi.org/10.1080/01904167.2017.1385811.

2. Yildiz, M.; Terzi, H. Effect of $\mathrm{NaCl}$ Stress on Chlorophyll Biosynthesis, Proline, Lipid Peroxidation and Antioxidative Enzymes in Leaves of Salt-Tolerant and Salt-Sensitive Barley Cultivars. J Agr Sci 2013, 19, 79-88, https://doi.org/10.1501/Tarimbil_0000001232.

3. El Goumi, Y.; Fakiri, M.; Lamsaouri, O.; Benchekroun, M. Salt stress effect on seed germination and some physiological traits in three Moroccan barley (Hordeum vulgare L.) cultivars. J Mater Environ Sci 2014, 5, 625-632.

4. Khosravinejad, F.; Heydari, R.; Farboodnia, T. Effects of salinity on photosynthetic pigments, respiration, and water content in two barley varieties. Pakistan J Biol Sci 2008, 11, 2438-2442, https://doi.org/10.3923/pjbs.2008.2438.2442.

5. Espasandin, F.D.; Calzadilla, P.I.; Maiale, S.J.; Al, E. Overexpression of the arginine decarboxylase gene improves tolerance to salt stress in Lotus tenuis plants. J Plant Growth Regul 2018, 37, 156-165, https://doi.org/10.1007/s00344-017-9713-7.

6. Hasanuzzaman, M.; Oku, H.; Nahar, K.; Bhuyan, M.H.M.B.; Mahmud, J.A.; Baluska, F.; Fujita, M. Nitric oxide-induced salt stress tolerance in plants: ROS metabolism, signaling, and molecular interactions. Plant Biotechnol Rep 2018, 12, 77-92, https://doi.org/10.1007/s11816-018-0480-0.

7. Panuccio, M.R.; Jacobsen, S.E.; Akhtar, S.S.; Muscolo, A. Effect of saline water irrigation on seed germination and early seedling growth of the halophyte quinoa. AoB Plants 2014, 6, https://doi.org/10.1093/aobpla/plu047.

8. Sevengor, S.; Yasar, F.; Kusvuran, S.; Ellialtioglu, S. The effect of salt stress on growth, chlorophyll content, lipid peroxidation and antioxidative enzymes of pumpkin seedling. Afr J Agric Res 2011, 6, 4920-4924.

9. Yasar, F.; Ellialtioglu, S.; Yildiz, K. Effect of salt stress on antioxidant defense systems, lipid peroxidation, and chlorophyll content in green bean. Russ $J$ Plant Physl 2008, 55, 782-786, https://doi.org/10.1134/S1021443708060071.

10. Taghipour, F.; Salehi, M. The study of salt tolerance in Iranian barley (Hordeum vulgare L.) genotypes in seedling growth stage. Am Eu J. Agric. Environ. Sci 2008, 4, 525-529.

11. Allel, D.; Ben-Amar, A.; Badri, M.; Abdelly, C. Salt tolerance in barley originating from harsh environment of North Africa. Aust J Crop Sci 2016, 10, 438-51, https://doi.org/10.21475/ajcs.2016.10.04.p6663x.

12. Binott, J.J.; Owuoche, J.O.; Bartels, D. Physiological and molecular characterization of Kenyan barley (Hordeum vulgare L.) seedlings for salinity and drought tolerance. Euphytica 2017, 213, 139, https://doi.org/10.1007/s10681-017-1924-2.

13. De Souza Freitas, W.E. ; de Oliveira, A.B.; Mesquita, R.O.; de Carvalho, H.H. ; Prisco, J.T.; Gomes-Filho, E. Sulfur-induced salinity tolerance in lettuce is due to a better $\mathrm{P}$ and $\mathrm{K}$ uptake, lower $\mathrm{Na} / \mathrm{K}$ ratio and an efficient antioxidative defense system. Sci Hortic-amsterdam 2019, 257, 108764, https://doi.org/10.1016/j.scienta.2019.108764.

14. Thouraya, R.; Imen, I.; Riadh, I.; Ahlem, B.; Hager, J. Effet du stress salin sur le comportement physiologique et métabolique de trois variétés de piment (Capsicum annuum L.) J. Appl. Biosci 2013, 66, 5060-5069, https://doi.org/10.4314/jab.v66i0.95004.

15. Patankar, H.V.; Al-Harrasi, I.; Al Kharusi, L.; Jana, G. A.; Al-Yahyai, R.; Sunkar, R.; Yaish, M.W. Overexpression of a Metallothionein 2A Gene from Date Palm Confers Abiotic Stress Tolerance to Yeast and Arabidopsis thaliana. Int J Mol Sci 2019, 20, 2871, https://doi.org/10.3390/ijms20122871.

16. Turan, M.A.; Hassan, A.; Taban, N.; Taban, S. Effect of salt stress on growth, stomatal resistance, proline and chlorophyll concentrations on maize plant. Afr J Agric Res 2009, 4, 893-897.

17. Azooz, M.M.; Shaddad, M.A.; Abdel-latef, A.A. Leaf growth and $\mathrm{K}^{+} / \mathrm{Na}^{+}$ratio as an indication of the salt tolerance of three sorghum cultivars grown under salinity stress and iaa treatment. Acta Agron Hung 2004, 52, 287-296, https://doi.org/10.1556/AAgr.52.2004.3.10. 
18. Gadallah, M. Effects of proline and glycinebetaine on Vicia faba responses to salt stress, Biol Plantarum 1999, 42, 249-257, https://doi.org/10.1023/A:1002164719609.

19. Jamil, M.; Lee, K.; J., Kim, J.; M., Kim, H.S.; Rha, E.S. Salinity reduced growth ps2 photochemistry and chlorophyll content in radish. Sci agric 2007, 64, 111-118, http://dx.doi.org/10.1590/S010390162007000200002.

20. Pinheiro, H.A.; Silva, J.V.; Endres, L.; Ferreira, V.M.; Camara, C.A.; Cabral, F.F.; Oliveira, J.F.; Carvalho, L.W.T.; Santos, J.M.; Santos. B.G. Leaf gas exchange, chloroplastic pigments and dry matter accumulation in castor bean (Ricinus communis L) seedlings subjected to salt stress conditions. Ind Crop Prod 2008, 27, 385-392, https://doi.org/10.1016/j.indcrop.2007.10.003.

21. Santos, C.V. Regulation of chlorophyll biosynthesis and degradation by salt stress in sunflower leaves. Sci Hortic-amsterdam 2004, 103, 93-99, https://doi.org/10.1016/j.scienta.2004.04.009.

22. Taïbi, K.; Taïbi, F.; Abderrahim L.A.; Ennajah, A.; Belkhodja, M.; Mulet, J.M. Effect of salt stress on growth, chlorophyll content, lipid peroxidation and antioxidant defense systems in Phaseolus vulgaris L. S Afr J Bot 2016, 105, 306-312, https://doi.org/10.1016/j.sajb.2016.03.011.

23. Athar, H.; Zafar, Z.U.; Ashraf, M. Glycinebetaine improved photosynthesis in canola under salt stress: evaluation of chlorophyll fluorescence parameters as potential indicators. J Agron Crop Sci 2015, 201, 428442, https://doi.org/10.1111/jac.12120.

24. Bates, L.S.; Waldern, S.P.; Teare, I.D. Rapid determination of free proline for water-stress studies. Plant Soil 1973, 39, 205-207, https://doi.org/10.1007/bf00018060.

25. Burnison, B.K. Modified dimethyl sulfoxide (DMSO) extraction for chlorophyll analysis of phytoplankton. Can J Fish Aquat Sci 1980, 37, 729-732, https://doi.org/10.1139/f80-095.

26. Arnon, D.I. Copper enzymes in isolated chloroplasts. Polyphenoloxidase in Beta vulgaris. Plant Physiol. 1949, 1-15, https://doi.org/10.1104/pp.24.1.1.

27. Maclntyre, I. Flame photometry. Adv Clin Chem 1961, 4, 1-28, https://doi.org/10.1016/S00652423(08)60033-5.

28. Miller, O.R. Nitric-perchloric acid wet digestion in an open vessel. In Kalra YP (eds) Handbook of reference methods for plant analysis. CRC Press 1998, 57-61.

29. Turan, M.A.; Elkarim, A.H.A.; Taban, N.; Taban, S. Effect of salt stress on growth and ion distribution and accumulation in shoot and root of maize plant. Afr J Agric Res 2010, 5, 584-588.

30. Ben Ahmed, H.; Manaa, A.; Zid, E. Tolerance à la salinite d'une poaceae à cycle court: La setaire (Setaria verticillata L.). CR Biol 2008, 331, 164-170, https://doi.org/10.1016/j.crvi.2007.12.002.

31. Gharby, S.; Hajib, A.; Ibourki, M.; Sakar, E.H.; Nounah, I.; El Moudden, H.; Elibrahimi, M.; Harhar, H. Induced changes in olive oil subjected to various chemical refining steps: A comparative study of quality indices, fatty acids, bioactive minor components, and oxidation stability kinetic parameters. Chem Data Collect 2021, 33, 100702, https://doi.org/10.1016/j.cdc.2021.100702.

32. Shahbaz, M.; Ashraf, M.; Al-Qurainy, F.; Harris, P. J. C. Salt tolerance in selected vegetable crops. Crit Rev Plant Sci 2012, 31, 303-320, https://doi.org/10.1080/07352689.2012.656496.

33. Sairam, R.K.; Rao, V.K.; Srivastava, G.C. Differential response of wheat genotype to long term salinity stress in relation to oxidative stress, antioxidant activity and osmolyte concentration. Plant Sci 2002, 163, 10371046, https://doi.org/10.1016/S0168-9452(02)00278-9.

34. Arzani, A.; Ashraf, A. Smart engineering of genetic resources for enhanced salinity tolerance in crop plants. Crit Rev Plant Sci 2016, 35, 146-189, https://doi.org/10.1080/07352689.2016.1245056.

35. Arzani, A. Improving salinity tolerance in crop plants: a biotechnological view. In Vitro Cell Dev. Biol Plant 2008, 44, 373-383, https://doi.org/10.1007/s11627-008-9157-7.

36. Long, N.V.; Dolstra, O.; Malosetti, M.; Kilian, B.; Graner, A.; Visser, R.G.F.; van der Linden, C.G. Association mapping of salt tolerance in barley (Hordeum vulgare L.). Theor Appl Genet 2013, 126, 23352351, https://doi.org/10.1007/s00122-013-2139-0.

37. Mano, Y.; Takeda, K. Heritability of salt tolerance at germination based on parent-off spring correlation and selection response in barley (Hordeum vulgare L.). Breeding Sci 1997, 47, 353-358, https://doi.org/10.1270/jsbbs1951.47.353.

38. Somasundaram, R.; Sood, N.; Swarup, G.T.; Subramanian, R. Assessing salt-stress tolerance in barley. Univ Sci 2019, 24, 91-109, https://doi.org/10.11144/Javeriana.SC24-1.asst.

39. Zhao, H.; Ni, S.; Cai, S.; Zhang, G. Comprehensive dissection of primary metabolites in response to diverse abiotic stress in barley at seedling stage. Plant Physiol Bioch 2021, 161, 54-64, https://doi.org/10.1016/j.plaphy.2021.01.048. 
40. Jabeen, Z.; Hussain, N.; Irshad, F.; Zeng, J.; Tahir, A.; Zhang, G. Physiological and antioxidant responses of cultivated and wild barley under salt stress. Plant, Soil Environ 2020, 66, 334-344, https://doi.org/10.17221/169/2020-PSE.

41. Akhter, M. S.; Noreen, S.; Mahmood, S.; Ashraf, M.; Alsahli, A. A.; Ahmad, P. Influence of salinity stress on PSII in barley (Hordeum vulgare L.) genotypes, probed by chlorophyll-a fluorescence. J King Saud Univ Sci 2021, 33, 101239, https://doi.org/10.1016/j.jksus.2020.101239.

42. Elsheery, N.I.; Cao, K.F. Gas exchange, chlorophyll fluorescence, and osmotic adjustment in two mango cultivars under drought stress. Acta Physiol Plant 2008, 30, 769-777, https://doi.org/10.1007/s11738-0080179-X.

43. Widodo, P.J.H.; Newbigin, E.; Tester, M.; Bacic, A.; Roessner, U. Metabolic responses to salt stress of barley (Hordeum vulgare L.) cultivars, Sahara and Clipper, which differ in salinity tolerance. J Exp Bot 2009, 60, 4089-4103, https://doi.org/10.1093/jxb/erp243.

44. Güngör, H.; Çıkılı, Y.; Dumlupınar, Z. Screening of oat varieties and landraces at early vegetative stage under salt stress conditions: Morpho-physiological and PCA biplot analysis. Cereal Res Commun 2021, 1-11, https://doi.org/10.1007/s42976-021-00138-0.

45. Tejera, N.A.; Soussi, M.; Lluch, C. Physiological and nutritional indicators of tolerance to salinity in chickpea plants growing under symbiotic conditions. Environ Exp Bot 2006, 58, 17-24, https://doi.org/10.1016/j.envexpbot.2005.06.007.

46. Serrano, R.; Mulet, J.M.; Rios, G.; Marquez, J.A.; De Larrinoa, I.F.; Leube, M.P.; Mendizabal, I.; PascualAhuir, A.; Proft, M.; Ros, R.; Montesinos, C. A glimpse of the mechanisms of ion homeostasis during salt stress. J Exp Bot 1999, 50, 1023-1036, https://doi.org/10.1093/jxb/50.special_issue.1023.

47. Munns, R.; M. Tester. Mechanisms of salinity tolerance. Annu Rev Plant Biol 2008, 59, 651-681, https://doi.org/10.1146/annurev.arplant.59.032607.092911.

48. Sun, Y.; Kong, X.; Li, C.; Liu, Y.; Ding, Z. Potassium retention under salt stress is associated with natural variation in salinity tolerance among Arabidopsis accessions. Plos One 2015, 10, 0124032, https://doi.org/10.1371/journal.pone.0124032.

49. Per, T.S.; Khan, N.A.; Reddy, P.S.; Masood, A.; Hasanuzzaman, M.; Khan, M.I.R.; Anjum, N.A. Approaches in modulating proline metabolism in plants for salt and drought stress tolerance: Phytohormones, mineral nutrients and transgenics. Plant Physiol Bioch 2017, 115, 126-140, https://doi.org/10.1016/j.plaphy.2017.03.018.

50. Fu. L.; Shen, Q.; Kuang, L.; Yu, J.; Wu, D.; Zhang, G. Metabolite profiling and gene 530 expression of Na/K transporter analyses reveal mechanisms of the difference in 531 salt tolerance between barley and rice. Plant Physiol Bioch 2018, 130, 248-257, https://doi.org/10.1016/j.plaphy.2018.07.013.

51. Ziemann, M.; Kamboj, A.; Hove, R.M.; Loveridge, S.; El-Osta, A.; Bhave, M. Analysis of the barley leaf transcriptome under salinity stress using mRNA-Seq. Acta Physiol Plant 2013, 35, 1915-1924, https://doi.org/10.1007/s11738-013-1230-0.

52. Misra, N.; Gupta, A.K. Effect of salt stress on proline metabolism in two high yielding genotypes of green gram. Plant Sci 2005, 169, 331-339, https://doi.org/10.1016/j.plantsci.2005.02.013.

53. James, R.A.; Davenport, R.J.; Munns, R. Physiological characterization of two genes for Na+ exclusion in durum wheat, Nax1 and Nax2. Plant Physiol 2006, 142, 1537-1547, https://doi.org/10.1104/pp.106.086538.

54. Dell'Aversana, E.; Hessini, K.; Ferchichi, S.; Fusco, GM; Woodrow, P.; Ciarmiello, LF; Abdelly, C.; Carillo, P. Salinity Duration Differently Modulates Physiological Parameters and Metabolites Profile in Roots of Two Contrasting Barley Genotypes. Plants 2021, 10, 307, https://doi.org/10.3390/plants10020307.

55. Vasilakoglou, I.; Dhima, K.; Giannakoula, A.; Dordas, C.; Skiada, V.; Papadopoulou, K. Carbon Assimilation, Isotope Discrimination, Proline and Lipid Peroxidation Contribution to Barley (Hordeum vulgare) Salinity Tolerance. Plants 2021, 10, 299, https://doi.org/10.3390/plants10020299.

56. Chen, Z.H.; Zhou, M.X.; Newman, I.A.; Mendham, N.J.; Zhang, G.P.; Shabala, S. Potassium and sodium relations in salinised barley tissues as a basis of differential salt tolerance. Funct Plant Biol 2007, 34, 150162, https://doi.org/10.1071/FP06237.

57. Wu, D.; Cai, S.; Chen, M.; Ye, L.; Zhang, H.; Dai, F.; Zhou, M.; Chen, Z.; Zhang, G. Tissue metabolic responses to salt stress in wild and cultivated barley. Plos One 2013, 8, 55431, https://doi.org/10.1371/journal.pone.0055431.

58. Zeeshan, M.; Lu, M.; Sehar, S.; Holford, P.; Wu, F. Comparison of Biochemical, Anatomical, Morphological, and Physiological Responses to Salinity Stress in Wheat and Barley Genotypes Deferring in Salinity Tolerance. Agronomy 2020, 10, 127, https://doi.org/10.3390/agronomy10010127. 
59. Sakar, E.H.; El Yamani, M.; Rharrabti, Y. Geometrical Traits in Almond Fruit as Affected by Genotypic and Environmental Variations in Northern Morocco. Erwerbs-Obstbau 2019, 61, 103-112, https://doi.org/10.1007/s10341-018-0401-y.

60. Sakar, E.H.; El Yamani, M.; Rharrabti, Y. Fruit Gravimetrical Traits in Almond [Prunus dulcis (Mill.) D.A. Webb]: Combined Effects of Genetic Control and Environmental Drivers. Erwerbs-Obstbau 2020, 62, 3746, https://doi.org/10.1007/s10341-019-00457-x.

61. Sakar, E.H.; El Yamani, M.; Boussakouran, A.; Ainane, A.; Ainane, T.; Gharby, S.; Rharrabti, Y. Variability of oil content and its physicochemical traits from the main almond [Prunus dulcis Mill. DA Webb] cultivars grown under contrasting environments in north-eastern Morocco. Biocatal Agric Biotechnol 2021, 32, 101952, https://doi.org/10.1016/j.bcab.2021.101952.

62. Zeroual, A.; Sakar, E.H.; Eloutassi, N.; Mahjoubi, F.; Chaouch, M.; Chaqroune, A. Wild chamomile [Cladanthus mixtus (L.) chevall.] collected from central-northern morocco: Phytochemical profiling, antioxidant, and antimicrobial activities. Biointerface Res Appl Chem 2021, 11, 11440-11457, https://doi.org/10.33263/BRIAC114.1144011457.

63. Arteaga, S.; Yabor, L.; Díez, M.J.; Prohens, J.; Boscaiu, M.; Vicente, O. The Use of Proline in Screening for Tolerance to Drought and Salinity in Common Bean (Phaseolus vulgaris L.) Genotypes. Agronomy 2020, 10, 817, https://doi.org/10.3390/agronomy10060817.

64. Zeroual, A.; Sakar, E.H.; Eloutassi, N.; Mahjoubi, F.; Chaouch, M.; Chaqroune, A. Phytochemical Profiling of Essential Oils Isolated Using Hydrodistillation and Microwave Methods and Characterization of Some Nutrients in Origanum compactum Benth from Central-Northern Morocco. Biointerface Res Appl Chem 2021, 11, 9358-9371, https://doi.org/10.33263/BRIAC112.93589371.

65. Alam, MS.; Tester, M.; Fiene, G.; Mousa, MAA. Early Growth Stage Characterization and the Biochemical Responses for Salinity Stress in Tomato. Plants 2021, 10, 712, https://doi.org/10.3390/plants10040712.

66. Askari, H.; Kazemitabar, S.K.; Zarrini, H.N.; Saberi, M.H. Salt tolerance assessment of barley (Hordeum vulagare L.) genotypes at germination stage by tolerance indices. Open Agric 2016, 1, 37-44, https://doi.org/10.1515/opag-2016-0005.

67. Boussakouran, A.; Sakar, E.H.; El Yamani, M.; Rharrabti, Y. Morphological Traits Associated with Drought Stress Tolerance in Six Moroccan Durum Wheat Varieties Released Between 1984 and 2007. J Crop Sci Biotechnol 2019, 22, 345-353, https://doi.org/10.1007/s12892-019-0138-0.

68. El Yamani, M.; Sakar, E.H.; Boussakouran, A.; Rharrabti, Y. Leaf water status, physiological behavior and biochemical mechanism involved in young olive plants under water deficit. Sci Hortic 2020, 261, 108906, https://doi.org/10.1016/j.scienta.2019.108906.

69. El Yamani, M.; Sakar, E.H.; Boussakouran, A.; Rharrabti, Y. Activity of two natural additives in improving the stability of virgin olive oil quality during storage. OCL 2020, 27, 44, https://doi.org/10.1051/ocl/2020039.

70. Sakar, E.H.; El Yamani, M.; Rharrabti, Y. Variability of oil content and its physico-chemical traits from five almond (Prunus dulcis) cultivars grown in northern Morocco. J Mater Environ Sci 2017, 8, 2679-2686.

71. El Yamani, M.; Sakar, E.H.; Boussakouran, A.; Rharrabti, Y. Influence of ripening index and water regime on the yield and quality of 'Moroccan Picholine' virgin olive oil. OCL 2020, 27, 19, https://doi.org/10.1051/ocl/2020015.

72. El Yamani, M.; Sakar, E.H.; Mansouri, F.; SerghinI-Caid, H.; Elamrani, A.; Rharrabti, Y. Effect of pigments and total phenols on oxidative stability of monovarietal virgin olive oil produced in Morocco. Riv Ital Sostanze Gr 2019, 96, 17-24.

73. El Yamani, M.; Sakar, E. H.; Boussakouran, A.; Ghabbour, N.; Rharrabti, Y. Physicochemical and Microbiological Characterization of Olive Mill Wastewater (OMW) from Different Regions of Northern Morocco. Environ Technol 2019, 1-13, https://doi.org/10.1080/09593330.2019.1597926.

74. El Yamani, M.; Sakar, E. H.; Boussakouran, A.; Benali, T.; Rharrabti, Y. Antioxidant activity of phenolic extracts from olive mill wastewater and their influence on virgin olive oil stability. Mor J Chem 2019, 7, 211223.

75. El Yamani, M.; Sakar, E.H.; Boussakouran, A.; Rharrabti, Y. Physiological and biochemical responses of young olive trees (Olea europaea L.) to water stress during flowering. Arch Biol Sci 2019, 71, 123-132, https://doi.org/10.2298/ABS181001054E.

76. Wu, D.; Shen, Q.; Cai, S.; Chen, Z.H.; Dai, F.; Zhang, G.P. Ionomic responses and correlations between elements and metabolites under salt stress in Wild and cultivated barley. Plant Cell Physiol 2013, 54, 19761988, https://doi.org/10.1093/pcp/pct134. 
77. Boussakouran, A.; El Yamani, M.; Sakar, E.H.; Rharrabti, Y. Genetic Advance and Grain Yield Stability of Moroccan Durum Wheats Grown under Rainfed and Irrigated Conditions. Int J Agron 2021, 5571501, https://doi.org/10.1155/2021/5571501.

78. Sakar, E.H.; El Yamani, M.; Boussakouran, A.; Rharrabti, Y. Genotypic and Environmental Variations in Kernel Color Indices in the Main Almond [Prunus dulcis (Mill.) D.A. Webb] Cultivars Grown in Northeastern Morocco. Scientifica 2021, 2021, https://doi.org/10.1155/2021/9970223.

79. Sivakumar, J.; Prashanth, J.E.P.; Rajesh, N.; Reddy, S.M.; Pinjari, O.B. Principal component analysis approach for comprehensive screening of salt stress-tolerant tomato germplasm at the seedling stage. J Biosci 2020, 45, 141, https://doi.org/10.1007/s12038-020-00111-9.

80. Abulfaraj, A.A. Stepwise signal transduction cascades under salt stress in leaves of wild barley (Hordeum spontaneum). Biotechnol Biotechnol $\quad$ Equip $\quad \mathbf{2 0 2 0}, \quad 34, \quad 860-872$, https://doi.org/10.1080/13102818.2020.1807408.

81. Vasilakoglou, I.; Dhima, K.; Giannakoula, A.; Dordas, C.; Skiada, V.; Papadopoulou, K. Carbon Assimilation, Isotope Discrimination, Proline and Lipid Peroxidation Contribution to Barley (Hordeum vulgare) Salinity Tolerance. Plants 2021, 10, 299, https://doi.org/10.3390/plants10020299. 